\title{
The Concept of State Terrorism in Relation to Iran
}

Josef Kraus $^{1}$

\begin{abstract}
This paper analyses the concept of state terrorism in relation to the politics of the Islamic Republic of Iran. The author uses the typology elaborated by the American political scientist Gus Martin. Iranian domestic and international patronage and assistance are researched. This paper comes to the conclusion that Iran is involved in a broad spectrum of terrorist activities; however, the specific forms of terrorism are carried our autonomously and in various time periods. The most active period was during the 1980s and the least Iranian terrorist activity can be noticed in the second half of 1990s.
\end{abstract}

KEY WORDS:: Iran; State terrorism; Targeted killing; Middle East; Terrorism sponsorship.

Dedication: This text was written thanks to specific research project at Faculty of Social Sciences, Masaryk University (MUNI/A/1342/2014)

\section{INTRODUCTION}

From a scientific point of view, the concept of state terrorism comes with a number of semantic, conceptual, typological and ideological problems that make characterizing this phenomenon rather difficult. Not only is it complicated to create a widely accepted definition that would serve as a necessary basis for further research; there is also the issue of gathering relevant data and supporting certain causal relationships with evidence. However, the aforementioned problems do not necessarily mean that research should not be undertaken, a typology should not be attempted or that the term should not be applied in particular cases. This paper aims to analyze the concept of state terrorism, explaining the difficulties related to defining its key terms, creating a typology and collecting data. Further on, the paper shows possibilities for further research, using the Islamic Republic of Iran as an example.

Terrorism and the support it finds in Iran have become popular topics for debate amongst security experts, social scientists and the media, since the so-called 'Islamic Revolution' of 1979. Iran has often been marked as the most active state sponsor and perpetrator of terrorist acts against its surroundings as well as within its own borders, having a direct impact on international efforts to promote

1 Address: Josef Kraus, PhD., Department of Political Science, Faculty of Social Sciences at Masaryk University, Joštova 10, 60200 Brno, Czech Republic. E-mail: j.kraus@mail. muni.cz 
peace in the Middle East. Allegedly, its chief motifs are dominance in the region, avoiding a peaceful solution to the Arab-Israeli conflict and maintaining the stability of its own regime. The Iranian regime has undergone, over a period of time, significant changes - similar to other authoritarian regimes. There have also been changes related to its involvement in terrorist activities. Perhaps the greatest deal of involvement was seen through the 1980s, when the Velayat-e faqih regime (the name means 'guardianship of the Islamic jurist', where 'faqih', the jurist, is written 'faqaha' in the plural) slowly formed, established itself and strengthened its position through the use of revolutionary excitement, Islamic faith bordering on fanaticism and repressions targeted on political opponents and representatives of the former regime. There was an important part of this process which consisted in exporting the ideology of the revolution (as well as the Velayat-e faqih system) abroad, attempting to transform Arabian monarchies in the Middle East into Islamic republics. This effort was perpetrated mostly by Shiite groups.

At the same time, Iran was facing a big threat from abroad - the country was attacked by Iraq, with the exhausting and devastating war lasting a whole eight years. During the war, Iran not only fought against Saddam Hussein's regime, but also against other states in the region that supported it. Until the Gulf War (1990-1991), there were acts of terrorism and sabotage taking place in Kuwait, Bahrain and other countries. (Marschall, 2003, p. 34) One needs to look at these events in the context of a cruel and escalated military conflict that brought about a number of excessive measures - such as the employment of chemical weapons against Iran and Iran's use of child soldiers - as well as a great deal of suffering and fanaticism. After the war, Iran's relationships with other countries in the region gradually came back to normal. At the beginning of the 1990s, following the death of Ayatollah Khomeini, the main ideological leader of the revolution, the revolutionary excitement of the previous decade died down, being replaced by sheer pragmatism that expressed itself both in Iran's foreign policy and its support of terrorism. The situation inside the country calmed down, mainly due to the succession of the moderate Seyyed Ali Khamenei as the supreme leader, and the pragmatic technocrat Akbar Hashemi Rafsanjani as the country's fourth president. Aside from Khomeini's death, it was also the international political situation that had an effect on Iran's turn towards pragmatism.

The long and exhausting war with Iraq had finished and it was crucial for Iran to gain support from the West in order to revitalize the country economically. Also, the Soviet Union had broken down into a number of states, and Iran had to deal with each new state separately - especially in the Caucasus and Central Asia. The Iraqi invasion of Kuwait in 1990 and the subsequent international military 
intervention brought about a significant change in the balance of political power in the Gulf region, thus weakening Iran's attempts at exporting its revolution, as well as its support of terrorism. Robert Baer (2009, p. 90-100) describes this change in Iran as a transformation of a revolutionary rebel into a Napoleonic conqueror. A country that supported the export of the Shiite-led uprising changed into a country whose aim was no longer to lay waste to foreign cities and support popular unrest. Its new goals were establishing order, conquering new territories and expanding its influence. Still, it would be wrong to say that Iran's support of terrorist activities stopped dead in its tracks. To be more precise, the intensity of that support was much lower than in the 1980s. Also, the support of terrorist activities was much less conspicuous and more pragmatically targeted. (cf. Baer, 2009, Kraus, 2010)

\section{KEY TERMS AND CONCEPTS}

\section{$\underline{\text { Terrorism }}$}

In order to introduce and use the concept of state terrorism, it is, first of all, necessary to provide a definition of terrorism. This is mainly because the problems and ambiguities encountered while defining the concept of terrorism are similar to those encountered further on, when trying to define state terrorism. There is still no consensus as to the precise definition of terrorism, despite the efforts of social scientists, security experts and various institutions around the world. To put it plainly, every researcher or expert seems to have his or her own definition. The situation is complicated further by a great number of different typologies that complement, extend or contradict one another. Since this paper focuses on a very narrow segment of an otherwise fairly wide and diversified phenomenon, and the aim of this research does not lie in tackling the complicated issue of defining non-state terrorism, it would seem best to choose a definition which is most general and least controversial.

Therefore, for the needs of this research, we are going to choose Strmiska's (2001) definition, which characterizes terrorism as an overtly politically motivated, systematic use of violence, with its physical effects inferior to the primary aim of creating an impact far beyond the immediate victims and witnesses of the attack. Following from this definition are two main conditions that need to be met in order for us to characterize certain activities, means, attempts or strategies as terrorist in nature.

The first condition is political motivation, in the broadest sense of the word. This naturally includes motives that are, amongst others, religious and 
ideological. The second condition is embodied in the wide impact of the terrorist act, one that goes beyond immediate victims and onlookers. In order to pry into the particularities of Iranian terrorism, it is also important to define the victims of a terrorist attack. (Mareš, 2005, p. 21-22) This particular detail is crucial for certain experts. According to some definitions, terrorism - in order to be called by that name - needs to target innocent civilian population; such targeting must not be selective and the victims may not have any freedom of choice related to the place where the attack is performed, or its manner of performance. This premise enables some researchers to dismiss attacks against an invading or occupying military force as terrorism. However, this viewpoint is problematic, for a number of reasons. If the chief aim of the attack were to weaken an opponent's armed forces, lay destruction to its military equipment or compromise its military capabilities, such an act would not fall within even the broadest of definitions of terrorism (such as Strmiska's definition, above).

However, the situation becomes rather different if the chief aim of the attack is to demonstrate force, intimidate the occupying (or invading) force as well as the inhabitants in its country of origin, and cause the armed forces to pull out of the region in question. As a typical example of this type of terrorism that targets military installations, we might name the double suicide bomb attack in Lebanon in the summer of 1983. The attack targeted a U.S. army barracks (242 casualties) and a French military base (58 casualties). Responsibility was claimed by the military wing of Hezbollah, calling itself the Islamic Jihad and being created, organized and managed by a branch of the Iranian Special Forces, the al Quds (Mannes, 2004, p. 147). The obvious aim was to intimidate the U.S. and French armed forces and manipulate public opinion in their home countries, causing the troops to pull out of the region - which in fact happened, a few months later. Thus, the attacks fulfilled (Strmiska's) definition of terrorism - they were politically motivated and their psychological impact was felt both in the armed forces and in the public opinion in their respective countries. The fact that the victims were military - not civilian - was of very little importance.

A few distinctions are crucial for our further research. It is necessary to distinguish between subversive terrorism and repressive terrorism, state terrorism and non-state terrorism and, last but not least, domestic terrorism and international terrorism (depending on the territory where the terrorist activities take place). Subversive terrorism is defined as terrorism 'from the bottom up', aimed against the ruling authority. Repressive terrorist acts, on the other hand, are perpetrated by the government. These categories are not strictly outlined, and may often fade into one another. Repressive terrorism is often mistaken for state terrorism, and to make matters even more complicated, the state may use 
subversive violence against its enemies, especially abroad. It may also support non-state terrorism, both domestic and international, repressive or subversive. (Mareš, 2005, p. 36-37)

\section{$\underline{\text { State terrorism }}$}

Let us now focus on the concept of state terrorism in particular. As stated above, the main problem lies in the fact that there is no general consensus as to the definition of what came to be called state terrorism, state-sponsored terrorism or terrorism perpetrated by state structures. (cf. Mareš 2005, Strmiska 2001, Blakeley 2010, Cline and Alexander 1986, Martin 2006) The concept of state terrorism is not even codified in international law as an illegal act. However, actions that fall into the category of state terrorism do constitute a breach of international law. For instance, targeting civilians, whether it is at times of peace or war, violates the principles that are embedded in international treaties concerning human rights. Furthermore, attacking combatants is a legal measure at times of conflict, but certain actions are forbidden - for instance, killing POWs as well as exposing them to torture, humiliating treatment and punishment. Following up on this premise, Blakeley (2010, p. 15 - 16) infers that countries violating international conventions in this way might in fact be accused of state terrorism.

Raye Cline and Yonah Alexander (1986, p. 32), who use the term 'statesponsored terrorism', define it as the conscious use of violence (or a threat of violence) by an independent state (or sub-national groups that are approved of and supported by the state) to achieve strategic or political goals by means of intimidating the target population rather than the immediate (military or civilian) casualties, both real and subject to a threat. Such conscious use of violence needs to be a breach of law. This rather basic and fairly broad definition comprises three conditions for an act of state terrorism. The act must be perpetrated by a state or state-related (or state-supported) groups, and there must be a political motivation as well as the aim to intimidate and spread fear within the target population, far exceeding the small number of immediate victims and witnesses.

According to Blakeley (2010, p. 15), on the other hand, a definition of state terrorism needs to include four basic premises. Firstly, there must be a conscious act of violence (or a threat of such violence) against the people who the state is obliged to protect. Secondly, the act must be perpetrated by groups related to the state or supported by the state (including private security units and paramilitary groups). Next, the act (or threat) aims to provoke fear in a targeted segment of the population, who identify with the victim or victims, and last but not least, by 
means of this act, the targeted segment of population is forced to change their behavior in a particular way. The last point takes Cline and Alexander's definition one step further, claiming that the underlying motivation behind inducing fear in population is invoking a change in their behavior. However, the first premise is problematic, as it limits state terrorism to within the borders of the respective state. For example, subversive acts carried out abroad would not fall within this definition of state terrorism, for the state is not obliged to protect foreign citizens or military troops.

Martin (2006, p. 111) also puts forward a definition of state terrorism, even though his seems a little on the short side. In his view, state terrorism - also called 'terrorism from above' - is a type of terrorism perpetrated by governments, quasi-governmental agencies and personnel against perceived enemies. It is accompanied by the policies of repression, violence and intimidation. The violence and repression is targeted upon perceived enemies whom the state labeled as a threat to its own security interests. Martin gives a more complex treatment of the issue in his typology of the phenomenon.

Research in this area brings about a great number of problems. Gathering relevant data ranks amongst the more serious issues such research needs to concern itself with. Terrorism - being the politically loaded topic it is - easily falls prey to ideological bias, the different motivations of those performing security measures, and also the different political orientations of those who provide the data. What one describes as armed resistance against an occupying force may well be described as an act of terrorism by someone else. A well-planned attack perpetrated by the enemy may be described as a criminal act carried out by a psychopath, and vice versa. The issue of state terrorism is further complicated by the fact that while typical subversive terrorist groups tend to claim responsibility for their actions, the state, on the other hand, has a tendency to try to cover up its tracks. When a terrorist attack does take place, it is very difficult to determine by analytical methods whether it was an act of state terrorism. It is quite common that states accused of supporting terrorist activities vehemently deny responsibility and it is rather difficult to obtain unbiased information from primary sources.

Even in cases where the perpetrator is without any doubt linked to a particular state structure, it is still quite unclear whether his actions were independent (and thus we may not infer any state involvement) or whether it was a wellplanned mission ordered, assisted or acknowledged by a particular state. In cases where a state employee (member of a secret service, member of a government enforcement program, a diplomat etc.) is the perpetrator of a criminal act, Blakeley (2010, p. 20-21) claims it is important to note the reactions of the state who has been accused of supporting or ordering a terrorist act. If the state in 
question is unable or unwilling to criminally prosecute the person responsible, refuses to compensate the victims or tries to rationalize the act, it is possible to consider the state an accomplice in that particular crime. If, however, the state and its institutions attempt to prosecute the culprit by all legal and disciplinary means available, and there is no evidence that the state acted otherwise in similar situations, or in any way approved of such crimes, it is possible to view the culprit's actions as a crime, not as an act of state terrorism. However, at this point, it is necessary to complement Blakeley's argument - there are cases where the state simply sacrifices the perpetrator, punishing him accordingly, only to defend its position in front of the international community. This, however, does not make it any less an accomplice in an act of terrorism. To illustrate the argument, one may remember the two men from Libya who were accused of carrying out a bomb attack against a Pan Am flight that resulted in the plane crashing near the Scottish town of Lockerbie.

Given the reasons stated above, it is extremely difficult for a researcher to obtain enough relevant and verified data that are not tainted by political bias; it is equally difficult to provide correct interpretation, analysis and sort them into categories whose boundaries are often blurred and uncertain.

\section{Martin's typology of state terrorism}

Gus Martin, in his book Understanding Terrorism (2006, p. 117-122), categorizes state terrorism according to two criteria. The first criterion is the sphere of influence (or domain) - terrorism may be carried out on a domestic or international level. The second criterion is the type of sponsorship, where Martin distinguishes between patronage and assistance. Patronage means active involvement of and support from the state - the state takes part in the violence and repressions. Assistance, on the other hand, is a term describing a silent form of participation in acts of terrorism. In this way, the state takes part in repressions through agents and proxies. Assistance, unlike patronage, is less visible, and links to the state and its authorities are more difficult to determine. 
Table 1. Martins typology of state terrorism

\begin{tabular}{|l|l|l|}
\hline \multirow{2}{*}{ Domain } & \multicolumn{2}{|c|}{ Type of Sponsorship } \\
\cline { 2 - 3 } & Patronage & Assistance \\
\hline International & $\begin{array}{l}\text { International violence } \\
\text { conducted on government } \\
\text { orders }\end{array}$ & $\begin{array}{l}\text { International violence with } \\
\text { government encouragement } \\
\text { and support }\end{array}$ \\
\hline Domestic & $\begin{array}{l}\text { Domestic repression by } \\
\text { government personnel }\end{array}$ & $\begin{array}{l}\text { Domestic repression by pro- } \\
\text { government extremists }\end{array}$ \\
\hline
\end{tabular}

Source: Martin, 2006, p. 117

International patronage involves violence on an international level, ordered by the state and carried out by different groups or organizations. The state does not cease to organize or support these groups, even if their involvement in terrorist acts has been demonstrated publicly. Domestic patronage involves domestic repression carried out by state security personnel in overt policy of state-sponsored political violence. Domestic assistance, on the other hand, is a form of repression carried out by sympathetic proxies, mainly pro-government extremists or vigilante groups which are tolerated or supported by the state. International assistance, then, involves violence carried out with the government's approval, or answering the government's call. When the perpetrators are discovered, the state may or may not cease to support them, and it may or may not deny support for them.

\section{$\underline{\text { State support for terrorism - two typologies }}$}

There are a number of ways a state may support terrorist activities, whether it carries out assistance or patronage. Let us take a closer look at two typologies that attempt to categorize state support. Gus Martin lists four ways a state may support and uphold terrorist organizations. These are - moral support, technical support, selective participation and active participation. Moral support involves the state's (open or secret) acknowledgment of terrorist activities, particular tactics, whole terrorist groups and their motives. Technical support involves either active or indirect participation of the state in training, arms deliveries, supplying shelter etc. Martin notes that this form of support is fairly passive, and the state has the choice of promoting its aggressive foreign policy or denying any involvement whatsoever. Selective participation takes place when a state actively supports a single act of terrorism, or a series of such acts. In selective participation, the state is not involved in terrorist activities or their support for a 
long period of time. The last category - active participation - means the state is actively involved in terrorist operations. Its representatives may cooperate with an affiliated terrorist group, and they may even take part directly in the attacks or their preparation. (Ibid, p. $125-130$ )

Shaul Shay's (2005, p. 147-148) typology is more concrete and more concerned with the particular steps the state undertakes in its support of terrorism. Shay offers five categories - 1. propaganda and political support (public proclamations of support, denouncing critique of the terrorist group, approval of the group's actions), 2. directing the terror (leadership, coordination, supplying information needed to perform terrorist acts), 3. financing, 4. instruction and training (education and training in terrorist techniques), 5. transfer of arms and equipment supplies. It is this typology that will be used further on in the paper to characterize the main acts of support for terrorism, as perpetrated by Iran around the world.

\section{Applying Martin's typology to state terrorism as carried out by Iran}

When looking at Iran's history since the the 1980s, there can be found all four types of state terrorism - that is, both international and domestic patronage, as well as both international and domestic assistance. The intensity of the different forms of terrorism has been changing over time - there are periods with a high rate of state repressions against its own inhabitants and also periods where these repressions subsided, leading to a lessening of tension within the society. Also, a gradual shift from international patronage to a less conspicuous form of terrorism - international assistance - may be observed. In the following paragraphs, the paper demonstrates the use of Martin's typology on the most striking examples of state terrorism in Iran.

\section{International patronage}

In the case of Iran, international patronage is present both in its subversive form (as expected) and also in its repressive form (which is less common). The subversive form of international patronage involves the support of terrorist groups and organizations, with a view to enforcing Iran's foreign policy and its goals. Alternately, such support stems from ideological or religious proximity of these groups to the Iranian regime. Iran's involvement in international state terrorism was most active and aggressive in the early 1980s, when it was inspired by Khomeini's policy of exporting the Islamic revolution outside of its borders, 
especially to nearby monarchies in the Gulf region, considered by Khomeini to be sources of tyranny and oppression. In his view, a true Islamic society could not develop under a feudal regime, because the only true and just leaders were the clerics. Khomeini also attempted to instigate a mass rebellion against social injustice and foreign influences in the region.

His support for an Islamic revolution was not mere rhetoric, however. There were coup attempts and bomb attacks targeting embassies, industrial complexes and oil rigs, carried out in almost every other country in the Gulf region in the 1980s, especially in Kuwait, Bahrain and Saudi Arabia. In Iraq, the main vehicle of Iran's state terrorist activities was the al-Dawa party, which later became an important political force in the country after the overthrow of Saddam Hussein. (Takeyh, 2006, p. 64-65) Iran's terrorist activities brought about an atmosphere of distrust in the region. Other countries labeled Iran as a major security threat, which was used by Saddam Hussein as one of the pretexts for starting the IranIraq War, during which the countries systematically supported him, intimidated by the threat of Iranian terrorism.

Perhaps the most significant example of Iran's international patronage is its connection with Hezbollah in Lebanon, which is featured on a U.S. list of terrorist organizations. Hezbollah was founded with direct participation of the Iranian Revolutionary Guards in 1982. The Iranian goal was to unify the Shiite population against the Jewish enemy, which led to the establishment of Hezbollah (translated as 'The Party of God'). In its beginnings, the organization served as a platform for radical Shiite militants. Due to the presence of the Revolutionary Guards, Iran had a direct influence on creating the organizational structure of Hezbollah and its military and ideological orientation. The link between the Revolutionary Guards and Hezbollah may also be well demonstrated on the similarity of their emblems. (Azani, 2009, p. 60-63) Since its foundation, Hezbollah has been receiving significant support from Iran. This was confirmed by the Secretary General of Hezbollah himself - Hassan Nasrallah stated that ever since 1982, Hezbollah has been receiving moral, political and financial support from Iran, thanks to which a decisive victory over the enemy has been achieved - one that would not have been accomplished if it hadn't been for Iranian support. (Fars News Agency, 8. 2. 2012) Iran itself does not deny its connection with Hezbollah, and even goes so far as to publicly support it.

This was clearly demonstrated during the Israeli attack on Hezbollah's positions in Lebanon in the summer of 2006. Iran's supreme spiritual leader, Grand Ayatollah Ali Khamenei, voiced public support for his Shiite ally, encouraging the whole Muslim community to protect Hezbollah and rise up against the United States and Great Britain for their involvement with the Zionists 
and their efforts to root out Islam from the region. (Fars News Agency, 8. 8 . 2006) Aside from the moral, financial and political support, Iran was - through the units of its Revolutionary Guards - also directly involved in fights against the Israeli army in the 1980s. The Revolutionary Guards was also involved - besides providing instruction and training to Hezbollah - in the internal conflict within the Shiite community. It assisted Hezbollah in its fight against Amal. During that time, the Revolutionary Guards began establishing a Hezbollah outpost in southern Lebanon (the center being the well-known Valley of Bekaa), which was meant to be the first step in creating an Islamic republic, similar in fashion to Iran. (Abraham, 1996, p. 178-179) This organizational structure, established and supported by Iran, was later used - under direct supervision and control of Iranian authorities - to commit acts of terrorism. In the beginning, these activities consisted in bomb attacks, suicide attacks and kidnappings, targeting mostly foreigners. To list a few major attacks, there was the 1983 attack against the U.S. Embassy in Beirut, with 63 casualties and 120 wounded, the attack against the U.S. army barracks (242 American casualties) and the attack against the French military base (58 French military casualties). (Mannes, 2004, p. 147) As for kidnappings, Hezbollah was at its most active between 1982 and 1988; Shay $(2005$, p. 117) lists 55 cases of kidnapping foreigners, who were later used for the needs of Iran. Kidnappings of American citizens (the most famous being the abduction of CIA Chief William Buckley, who was executed in 1984, shortly after the incident) served towards exerting pressure on the United States in order to obtain a deal - an exchange of armaments for hostages, as Iran was experiencing a shortage of military equipment in its war with Iraq. The deal was indeed struck later on, culminating in the well-known Iran-Contra scandal. Up to this day, Iran has been involved - by means of its al-Quds forces - in creating operation plans for Hezbollah, as well as realizing them. Some members of the Hezbollah terrorist units answer directly to Teheran, and many of them have Iranian passports. (Byman, 2007, p. 90) Due to these reasons, Hezbollah has often been referred to as the proxy that is used to promote Iranian state terrorism. (cf. Azani 2009, Bergman 2008, Byman 2007, Mannes 2004, Napoleoni 2005, Shay 2005)

The repressive form of Iran's international patronage may be demonstrated by the example of eliminating the regime's political opponents, prominent figures of the former Shah's administration and other Iranians in exile. These are people murdered by Iranian secret services or other secret services linked to the Iranian regime. It is necessary to distinguish these assassinations from the so-called 'targeted killings' and define them as acts of state terrorism. If we are to speak of a targeted killing, a number of conditions need to be met. First of all, there must 
be an ongoing military conflict (international or local) - otherwise, it would be a regular murder. Next, the victim must not be chosen at random - he/she must display a connection with the conflict. Also, detaining or arresting the individual is not possible due to the context of his/her whereabouts, and last but not least, the individual needs to be an active participant in enemy activities - either as a regular combatant or as a spontaneous, unorganized enemy force. (Solis, 2010, p. 452 - 453) Iran's attacks towards its political opponents may not be regarded as targeted killing for a number of reasons.

First of all, it is impossible to label most of the victims as regular or spontaneous combatants. The victims were mostly writers, artists, intellectuals and caricaturists. The targets were also members of the Kurdish opposition and representatives of the former Shah's regime. Roya Hakakian speaks of at least 60 victims who were shot, stabbed or decapitated in all corners of the world, from Paris through Maryland, Manila, Bombay, Karachi, Istanbul, Vienna, Geneva, Stockholm, Tokyo and Bonn to New Jersey (2011, p. 36). Most of these people were killed during the Iran-Iraq war in the 1980s, so technically speaking, the first condition of 'targeted killing' would be met. However, most of the victims (excluding members of the People's Mujahedin - MEK - and some Kurdish representatives) had no connection with the conflict. Furthermore, one of the biggest attacks on members of Iranian and Kurdish opposition took place in Berlin in the Greek restaurant called Mykonos as late as 1992; that is, four years after the war had ended. The restaurant, which housed a meeting of the Iranian-Kurdish opposition, was invaded by two militants who opened fire on the people sitting there and debating. There were four victims in the shooting, the most significant of them being the Secretary General of the Democratic Party of Iranian Kurdistan, Sadegh Sharafkandi. Greater bloodshed was avoided by mere accident - most members of the meeting had mistaken the date and arrived a day later. (For more see Hakakian, 2011) The militants were Iranian and Lebanese citizens; the leader of the team was Abdul Rahman Bani Hashemi, who worked for the Iranian Ministry of Intelligence and National Security (VEVAK). (Kutchera)

Clearly, there was an element of threat in the way the attack was conducted - it did not take place on a secluded spot with the victims silently executed - it took place in the biggest city in Germany, at a public place and in a spectacular fashion, which became a media sensation all around the world. Therefore, the attack was perpetrated with the obvious aim of sending the Kurdish opposition and other dissenting voices a clear message - if they engage in some activity against Iran, they might meet a similar fate. The threatening element shows that this was an act of terrorism, not a simple murder or targeted killing. To take more 
recent examples of Iranian activities abroad, one may look at the recent attacks on Jewish and Israeli targets in Azerbaijan, Georgia, India and Thailand. It was especially the (failed) assassination attempts at the Israeli ambassador in Baku and high-ranking representatives of the Jewish community in the country that spurred international attention. According to the Ministry of National Security in Azerbaijan, these attacks were prepared by individuals linked to, organized by and paid by Iranian security services. (APA-Baku, 19. 1. 2012)

Two months following this incident, Azerbaijan arrested 22 people, accusing them of treason and espionage. Based on the official proclamation of the government authorities, the arrested individuals cooperated with the Iranian Revolutionary Guards, supplying them with information and involving themselves in the preparation of terrorist attacks and acts of sabotage aimed towards the U.S., Israeli and other foreign presence in Baku. (Ministry of National Security of Azerbaijan Republic, 14. 3. 2012) These events immediately fueled debates amongst security experts. Theories emerged that Azerbaijan is becoming a battlefield for Israeli and Iranian secret services, as well as a place where an asymmetric form of struggle takes place. (Radio Free Europe / Radio Liberty, 17. 2. 2012) The attack on a bus transporting Israeli tourists in the Bulgarian resort of Burgas on 18th June 2012 was also blamed on Iran and Hezbollah, especially in the United States and Israel media (Kulish and Schmitt, 2012); however, these claims have not yet been supported by evidence.

The fatwa against the writer Salman Rushdie might be seen as a peculiar act of international patronage. The fatwa was announced by Khomeini in 1989 in response to the author's allegedly blasphemous novel The Satanic Verses, and it was accompanied by the promise of a substantial reward to anyone who manages to kill Rushdie. The fatwa is still valid today and Rushdie lives under the protection of the British secret services. The edict was also extended to the publishers of the book, and there have been a number of assassinations and threats aimed at publishers around the world. (Laqueur, 1999, p. 176)

\section{$\underline{\text { International assistance }}$}

A country's international assistance in terrorist activities is in itself a problematic concept. The boundary between international assistance and international patronage is very unclear, and it is difficult to decide whether a particular form of support should be listed under assistance or patronage. In general, international assistance should involve a less direct, less pronounced and less conspicuous form of support, such as approving of and instigating terrorist attacks. According to Martin (2006, p. 20), it should involve an indirect help to a proxy who carries 
out an attack. In this way, the state should not take part directly in terrorist activities, managing them, planning them or taking responsibility for them. The state should rather act from a distance, providing ideological, rhetorical, financial and material support. In the case of Iran, we may speak of a number of terrorist organizations that get a greater or lesser deal of support from the regime, depending on their measure of involvement with it, their ideological orientation, their particular successes in terrorist activities as well as their compatibility with Iran's pragmatic political goals.

The last issue in particular is a case in point when it comes to the situation in Iran after the death of Khomeini, when the regime began to enforce a more pragmatic policy, in contrast with its former, more ideologically based goal of exporting the revolution abroad at any cost. It may be demonstrated on the fact that the regime failed to support the Islamist militants in Chechnya or the Uyghur Muslims in the Xinjiang province. In both of these cases, pragmatism won over ideology and Iran decided to prefer maintaining good relationships with its key allies, Russia and China, instead of providing religiously motivated support for the insurgents.

The different measures of support from Iran are best manifested in the example of the Shiite minority in the Gulf region (in the cases of Iraq and Bahrain, the Shiite constitute a majority). Even before the Iran-Iraq war broke out, Iran began supporting mass protest inspired by the Islamic revolution - especially in Bahrain, Saudi Arabia and Kuwait, although there were mass anti-government protests also in Qatar and United Arab Emirates. These protests were carried out, to a great extent, by radical Shiite groups. During the Iran-Iraq war and up until the Gulf War, there were reports of acts of violence and sabotage mostly in Bahrain and Kuwait. These attacks were perceived as Iran's revenge taken on countries that supported Iraq in the war. The calm post-war situation was interrupted at the end of 1994, when a Shiite uprising took place in Bahrain and the state, together with other countries in the Gulf region, perceived this as an attempt at a coup supported by Tehran. This led to the Gulf countries losing trust in Iran, as well as the Shiite minorities within their own borders. (Marschall 2003: 34)

An important millstone was the allied invasion of Iraq in 2003, which led to the so-called Iraqi uprising and Iran's subsequent rhetorical, material and financial support of Shiite groups, whose most prominent representative was Muqtada al-Sadr and his Mahdi army. This inspired Sunni leaders to describe the situation as the 'rise of the Shiite crescent', threatening to destabilize Gulf monarchies. (The Washington Post, 8. 12. 2004) Bahrain is a place where the Shiite majority (70\%) and the ruling Sunni minority often clash. Iran supported 
the local Shiite inhabitants in the 1980s and the 1990s via the Islamic Front for the Liberation of Bahrain - IFLB - a resistance group trained and financed by Iran, which called for the uprising of the whole Muslim community under the leadership of Ayatollah Khomeini, establishing an Islamic government and the liberation of Bahrain. After the Gulf War, Lebanon-based Hezbollah began its operations in Bahrain, allegedly with the support and participation of Iran, as stated by Bahraini authorities. (Marschall, 2003, p. 32) It is, however, difficult to label these groups as terrorist organizations, because they have not been involved in any terrorist activity. All they did was organize demonstrations, provoke unrest and plan to overthrow the regime - always with a measure of support from Iran, however.

Another significant example of Iranian international assistance is the country's support for the Palestinian militant movement, Hamas. The movement is not as closely tied to the regime as Hezbollah in Lebanon, mainly due to the different ideological background - the Sunni Hamas is not really compatible with the Shiite regime in Iran. Also, there is an absence of Iranian involvement in forming the movement and the management of its terrorist activities. The former spiritual leader of Hamas, Ahmed Yassin, was radically opposed to any support coming from Iran. The reasons were in part ideological, but there was also the possibility of damaging Hamas' prospects of obtaining financial support abroad - especially in Europe and the United States, but also from his Arabian patrons. Yassin also strove for the greatest possible autonomy of Hamas, which would be scarcely imaginable had Iran been involved in coordinating or managing terrorist activities, let alone in demanding the physical presence of its representatives in the organization. (Bergman, 2008, p. 214 - 215)

Therefore, Iran's biggest involvement with Hamas is in the way of rhetorical support, which limits itself to its anti-Israeli position (and avoids commenting on Hamas' religious profile), and also financial support. The financial support from Iran grew massively, following the Palestinian legislative election of 2006, when, in response to Hamas' victory, the Quartet cut funds to the Palestinian Authority. Due to this financial boycott, Iran became the main sponsor of the Authority, and therefore also the main sponsor of the dominant Hamas. For the year 2010, Hamas confirmed its budget of 540 million USD, while at least 60 million was expected to be collected from taxes and various fees. The rest was to be obtained from sponsors abroad, the largest of which was to be Iran. The President of the Palestinian National Authority, Mahmoud Abbas, said that Hamas receives 250 million USD from Tehran every year. (WorldTribune, 5. 1. 2010) 


\section{Domestic patronage}

Shortly after the Islamic revolution in Iran, a system of repressions was set up against the prominent figures of the former regime, as well as against the critics of the new one. In the first two years after the revolution, there were hundreds of executions, murders and disappearances of former politicians, higher army officers, agents of the Shah's secret police and a number of ideological or political opponents of the regime of Imam Khomeini and his loyal Shiite clerics. The repressions escalated as late as 1981, when the regime adopted drastic measures against opposition groups, especially the People's Mujahedin (Mujahedin-e Khalq - MKO, PMOI). Amnesty International claimed there were 2616 executions, but the real number is probably much higher. There were a lot of executions of women and youngsters. (Fidh, 2009) Islamic Revolutionary Committees (komiteh) were established, forming a somewhat autonomous organization, which at the beginning of the revolution coordinated strikes and demonstrations and later began to suppress the opposition to the regime in a violent way. Together with the police, they pursued political activists, drug dealers and people breaking Islamic laws. Komiteh engaged especially in the last mentioned point, acting as a sort of religious police that kept watch over the way women dressed and assaulted places where parties involving alcohol took place. In 1990, under the influence of the fourth president of Iran, Akbar Hashemi Rafsanjani, and the parliament, these revolutionary committees were transformed into Forces of Order, Niruha-ye Entezami. (Buchta, 2000, p. 65)

These were formally organized by the Ministry of the Interior (but in fact they fell under the competence of the Revolutionary Guards) and they operated on a national level, specializing in drug trade, border patrol and security measures during demonstrations and uprisings. Niruha-ye Entezami were criticized during the student uprising of 1999, where they either participated in suppressing the demonstrations, or were inactive when the radical-conservative vigilante group Ansar-e Hezbollah ('the supporters of the party of God') attacked the demonstrators. The vigilante group focuses on upkeep of the moral standards of Islamic morality in the society and suppressing opposition and resistance to the regime. (Wehrey, 2009, p. 10-11)

The issue of domestic patronage becomes problematic when considering the Basij, a voluntary paramilitary organization that fulfilled military tasks during the Iran-Iraq war but has specialized, since the beginning of the 1990s, in internal security issues such as suppressing unrest and keeping watch over Islamic moral standards in the society. In the event of a war, the members should serve as reserves of the Revolutionary Guards, who also controls the organization. The number of 
militants who are members of Basij is estimated at between 100,000 to 300,000 active members. However, the organization's mobilization capacity reaches at least one million, and keeps rising. (Cordesman and Kleiber, 2007, p. 81) However, people's motivations to join the organization are not purely ideological. Some members welcome the fact that they need not enter compulsory military service, others see the prospects of social and economic profit. Besides the fact that members of the organization accept financial compensation (however, this is not defined as salary), they also find it easier to achieve university education, get loans from banks or be employed in the state sector. At universities, the members are used as an extended controlling organ of the regime amongst both teachers and students.

This was most evident during Mahmoud Ahmadinejad's term as president (from 2005), when significant purges took place at universities, with the vacated positions filled with members of the organization. These loyal teachers then formed an organization that was to exert their members' influence over other academics and their teaching. The thus formed teacher's association is said to have over 15,000 members, which comprises about one fourth of all university teachers. However, there is also the Basij student organization, numbering approx. 650,000 members at 700 Iranian institutions of higher education. This organization plans coordinated confrontations with reformist activists, exerts influence on school authorities with a view to improving moral and political standards at their respective institutions and serves as a coordinating body in the case of mobilization (Wehrey, 2009, p. $39-41$ ). These functions were put into practice especially in 2009 , following the reelection of Mahmoud Ahmadinejad. Young people, who felt cheated in the election, radicalized - and universities became the centers of resistance. The members of Basij organizations were then used to quell the unrest and eliminate the leaders of the resistance and their supporters (many of whom were then arrested, beaten, tortured - or disappeared altogether).

The privileges that members of the organization receive - otherwise quite inaccessible for most of the population - become a greater stimulus for them than the religious or ideological closeness to the regime or the organization's goals. In the recent years, with the members' ascension into civil service and the Revolutionary Guards, these people are beginning to hold key positions in state industries and foundations. Holding these positions involves a great number of benefits, including university education and financial compensation. Since these people's activities are directly controlled and managed by the Revolutionary Guards, it is difficult to perceive this organization as a mere vigilante group or a movement of pro-government extremists.

The author of this paper believes that, following from these arguments, the 
organization is an example of domestic patronage rather than domestic assistance of terrorism, even though the boundary between the two is - in this case - rather unclear and changeable. Also, it is necessary to distinguish between Basij de iure - a voluntary organization with common ideological and religious goals (suitable to be listed under 'domestic assistance') - and Basij de facto - an organization that is financially, personally and in terms of organization related to and dependent on the Revolutionary Guards; with the task of using repressive measures against enemies of the regime. Its members are in fact professionals, even though their compensation may not be solely financial. Given the latter description, the organization should be listed under 'domestic patronage', according to Martin's understanding of the term.

\section{Domestic assistance}

If the Basij - as Iran's most prominent paramilitary group - was categorized within the sector of domestic patronage, then perhaps the most significant representative of domestic assistance is the aforementioned organization named Ansar-e Hezbollah. This Islamist vigilante group focuses its activities on imposing Islamic moral standards on citizens and suppressing opposition against the regime as well as any form of protest. Ansar-e Hezbollah is made up of exmembers of the Revolutionary Guards, Basij and the veterans of the Iran-Iraq war. Although Ansar-e Hezbollah and the Revolutionary Guards share the same ideological background (as well as some of their members), the former is not in any way controlled by the latter (Wehrey, 2009, p. 22). Members of the group are not bound by any code of conduct and they usually perform spontaneous acts of violence against all perceived enemies of the regime and its values. The victims of these vigilante groups are pro-reformist or dissenting journalists, religious figures, artists, political activists etc. Units of Ansar-e Hezbollah are being created all across the country and their hierarchical structure is neither rigid nor sophisticated. At times of elections, these groups repeatedly attack pro-reformist political gatherings, demolish offices of pro-reformist politicians and physically abuse and threaten anyone who they perceive as problematic. In 2003, members of the movement entered student dormitories in Tehran, destroying property and wounding over 50 students (United States Department of State).

Even though the authorities tolerate the movement's attacks on the enemies of the regime (and sometimes they go so far as to support them), there are times when the activities of Ansar-e Hezbollah are perceived by the regime as problematic or even counter-productive, exceeding the measure of repressions as tolerated by the state. One of the most significant examples of this is the clash 
between the vigilante groups and the Forces of Order, Niruha-ye Entezami, in Mashhad in 2003, resulting in the arrest of the local leader of Ansar-e Hezbollah and three other high-ranking officials Wehrey $(2009$, p. 11, 88). claims this was the culmination of tensions between the Revolutionary Guards and paramilitary vigilante groups. The paramilitaries were a threat to the political ambitions of Mohammad-Bagher Ghalibaf, who was also the one who ordered their pacification. This brought him quite some popularity with the inhabitants, which he used later in 2005 to run for president. After being defeated by Mahmoud Ahmadinejad, he took over from him the post of the mayor of Tehran, which he has held until today.

The intensity and inter-connectedness of the different forms of Iranian state terrorism

Due to the unavailability or incompleteness of raw data, it is difficult to determine the intensity of the different forms of Iranian state terrorism by quantitative means. The researcher encounters a number of major obstacles at the same time. First of all, there is no complete and reliable database that would provide a longterm record of Iranian terrorist acts based on a pre-defined methodology, one that could be used as a basis for research, in order to quantify Iranian terrorism. This is mainly due to the fact that the existing complex databases - such as the Global Terrorism Database hosted by the University of Maryland or the Database of Worldwide Terrorism Incidents created by the RAND Corporation (see below) - record each terrorist act on a single level, listing only the direct perpetrator, but no third parties involved. In other words, these databases may record attacks carried out by Lebanon-based Hezbollah, but fail to mention Iran as an organizing force. Therefore, if we carry out a search in such a database, looking for 'Iran' as the originator of attacks, we will only find a list of attacks carried out against Iran and its territory, not those that Iran is responsible for. Moreover, the aforementioned databases only work with known terrorist groups, so there are no spontaneous assassinations, murders of opponents to the Iranian regime in exile, acts perpetrated by the Revolutionary Guards (which is not listed as a terrorist organization in these databases) and other indirect or proxy attacks.

Another possibility lies in making use of resources that focus solely on Iranian terrorist activity. A typical example is the Iran Terror Database (http://www. iranterror.com) which, however, stopped listing terrorist attacks in January 2005. Another valuable source is a project called United Against Nuclear Iran (www. unitedagainstnucleariran.com), which gives a timeline of Iranian state-sponsored terrorist activities. Yet another source would be Shaul Shay (2005), who gives 
a list of Iranian and Shiite terrorist activities, divided into groups according to a number of criteria. The main problem related to using these databases is the absence of methodology used in choosing the particular acts, labeling them as Iranian terrorism, as well as omitting some other terrorist activities. Even a superficial look at the two databases, the Iran Terror Database and United Against Nuclear Iran, reveals how incomplete they are.

Moreover, the United Against Nuclear Iran project reveals a clear ideological bias against Iran, which significantly devalues the information provided. In the case of Shay's materials, their lack of transparency basically rules out any possibility of verification, as there are no primary data. Due to the reasons stated above, these sources may be used only indirectly and there is no way any quantitative research could be based on them. Another problem with these sources is that they only work with specific acts of terrorism, neglecting indirect forms of support such as arms deliveries, funding or rhetorical propaganda. However, these data are crucial in understanding the intensity of Iranian terrorism or Iranian support of terrorism. Such data need to be obtained from other sources and later on merged with a list of terrorist acts. Furthermore, none of the databases offers a list of Iranian terrorist activities against inhabitants within its borders. Once again, the amount of repressive activity needs to be obtained from other sources which are difficult to quantify. When dealing with terrorist attacks only, it is possible to use the Global Terrorism Database and the Database of Worldwide Terrorism Incidents, with the aim of monitoring the activity of known terrorist groups that are supported by Iran in the form of international patronage or assistance.

The most important group, often labeled as Iran's proxy in carrying out terrorist attacks, is Lebanon-based Hezbollah, which was established in direct cooperation with the Iranian Revolutionary Guards and which has been working under the patronage of Iran. Both databases offer data regarding Hezbollah, but the two sets of data differ to a certain extent. This is due to the different sources the databases use, as well as their different definitions of a terrorist act. The Database of Worldwide Terrorism Incidents defines terrorism as a politically motivated act, usually targeted at civilians. However, it hurries to add a number of instances where an attack on a military target is also listed amongst terrorist attacks (USS Cole in Yemen). Global Terrorism Database allows visitors to filter out their search depending on three different criteria used in defining terrorism , so one may work with a single criterion or perhaps all three at once - whichever selection best suits his or her understanding of the concept. Global Terrorism Database recorded 363 terrorist attacks perpetrated by Hezbollah between 1983 and 2008. Hezbollah seems to have been most active (depending on the number of attacks ) between 1991 and 1995, and the intensity has been on the decrease 
ever since. The Database of Worldwide Terrorism Incidents lists 175 terrorist attacks between 1983 and 2005; there were 131 attacks until 1990 and 158 attacks until 1995 (which comes close to the total number of attacks listed).

Shaul Shay (2005, p. 81-85) offers his own statistics of Iranian terrorist activities as well as terrorist activities of Shiite groups related to Iran, between 1980 and 1999. These years allegedly saw 260 terrorist attacks. This list excludes Hezbollah's attacks against the Israeli army in Lebanon, as well as attacks against Iraqi targets during the Iran-Iraq war. Shay divides Shiite terror into four categories - kidnappings and abductions (approx. 26\% incidents), hijacking planes and bomb attacks on planes $(4.5 \%)$, timed bombings and car bombings $(31.5 \%)$ and assassinations (mostly shootings) (37\%). As for the geographical distribution of attacks, Shay lists 32 countries in total. Most attacks took place in the Middle East (173), with Europe on the second place (57), followed by Asia (23), the United States (6) and Africa (1). Shay also notes that 33\% terrorist attacks were aimed at Iranians in exile as well as opposition organizations. Following from his statistics, he makes several conclusions about the intensity of Iranian terrorism. During the rule of Ayatollah Khomeini (1979 - 1989), there were 171 international Shiite or Iranian terrorist attacks, while during the rule of Ayatollah Khamenei (1989 - 1999), there were 'only' 89 attacks, which means the number of attacks dropped by a half. Also, kidnappings of Western civilians in Lebanon stopped in 1990 and by 1992, all the hostages had been released. In 1989, all Shiite attacks against airplanes ceased, so there were no more hijacks or bomb attacks on civilian flights. On the other hand, the number of attacks against opposition organizations and Iranians in exile went up - these attacks were mostly perpetrated in Iraq, Turkey, Pakistan and France. However, the number of Western targets decreased.

The high era of Iranian and Iranian-sponsored international terrorism therefore happened in the 1980s, when the revolution ideology under the leadership of Ayatollah Khomeini was strongest, further enhanced by the bloody conflict with Iraq. However, the decreasing number of terrorist attacks perpetrated by Iran or its proxies does not signify that the phenomenon of Iranian terrorism is disappearing. It has only changed its form, presenting itself as direct patronage or indirect assistance. Today, the key form of terrorist support resides in providing military equipment, funds and political support for affiliated terrorist organizations. The high era of Iranian domestic terrorism also took place in the 1980s, with hundreds of executions, murders and abductions of prominent figures of the former regime and the critics of the new one. The work of the komiteh, Iranian religious police, was most visible during this era.

Shortly after the death of Ayatollah Khomeini, the atmosphere in Iranian 
society calmed down and there were fewer repressions; even the feared komiteh were transformed and brought under control in 1990. The more relaxed atmosphere in the society after the death of Khomeini was then slowly disrupted by an increase in Iranian terrorist activity, both abroad and within its borders (in the form of repressions). This corresponds with events and trends such as the election of Mahmoud Ahmadinejad as president, the rising importance of the Revolutionary Guards and the growing influence of conservatives in the Iranian parliament (or, rather than that, the withering influence of modernists and moderates around the former president Mohammad Khatami).

Iran is becoming a major supporter of terrorist groups that used to be separated from it either historically or ideologically. A good example is Hamas, who earlier shared very little common ground with Islamic Republic, but since the outbreak of the Second Intifada (2000), the U.S. invasion of Iraq (2003) and the death of Yasser Arafat (2004) has been receiving significant political and material support from Iran (Frisch, 2007). During this period, repressions in Iran were also on the rise, culminating after the 2009 presidential election when a massive uprising called for a response from the regime. Even though these events do not correlate with the intensity of Iran's international terrorist activity, they both stem out of the same political climate in the country.

\section{CONCLUSION}

The paper shows that the concept of state terrorism might be used to analyze those activities of the Islamic Republic of Iran that are somehow related to terrorism. Within the concept of state terrorism, Iranian international terrorism has already been studied by the leading expert in terrorism, Walter Laqueur, who looked into the phenomenon in the context of state terrorism carried out by the countries of the Soviet bloc during the Cold War, Libyan terrorism during Qaddafi's regime and terrorist activities perpetrated and supported by Saddam Hussein's regime in Iraq. (Laqueur, 1999, 156-183) However, it is also important to stress Iran's role in assisting major terrorist groups (Hamas, Hezbollah etc.), as well as the domestic, repressive component of state terrorism.

Iranian terrorism, carried out by state employees or affiliated paramilitary groups, as well as certain activities of Hezbollah, are peculiar in the sense that they are not directly followed by political proclamations or justifications. Frequently, these actions carry propaganda in themselves (an act of terrorism already carries the intended meaning or message), or appear as 'targeted killings'. An exception here would be the fatwa against Salman Rushdie and his publishers, which already carries in itself a justification of a future terrorist act (even though the act is presented primarily as 
religious punishment). Iranian domestic terrorism of the repressive type, on the other hand, is accompanied with political propaganda and a threatening message.

The data presented in this paper do not suggest an immediate correlation between the different forms of state terrorism, in the sense that one form in one period of time would be followed or conditioned by another form. However, it may be safe to say that the Iranian totalitarian regime, which has resorted to using elements of the terrorist repertoire, is able use and combine these elements depending on its current political goals and the current possibilities.

\section{REFERENCES}

ABRAHAM, A. J. 1996. Lebanon War. Westport: Greenwood Publishing Group. APA-Baku. 19. 1. 2012. Azerbaijani National Security Ministry prevents terrorist attack planned in Baku. Retrieved from July 15, 2015 from http://en.apa.az/ news.php?id $=164008$

AZANI, EITAN. 2009. Hezbollah: The Story of the Party of God. New York: Palgrave Macmillan.

BAER, ROBERT. 2009. The Devil We Know: Dealing with the New Iranian Superpower. New York: Crown Publishing Group.

BERGMAN, RONEN. 2008. The Secret War with Iran, New York: Free Press.

BLAKELEY, RUTH. 2010. "State Terrorism in the social sciences: Theories, methods and concepts", in JACKSON, RICHARD, MURPHY, EAMON and SCOTT POYNTING (eds.) Contemporary State Terrorism: Theory and practice. London: Routledge

BUCHTA, WILFRIED. 2000. Who Rules Iran?. Washington D.C.: The Washington Institute for Near East Policy.

BYMAN, DANIEL. 2007. Deadly Connections. New York: Cambridge University Press.

CLINE, RAY S. and YONAH ALEXANDER. 1986. Terrorism as StateSponsored Covert Warfare. Arlington: HERO Books.

CORDESMAN, ANTHONY and MARTIN KLEIBER. 2007. Iran's Military Forces and Warfighting Capabilities: The Threat in the Northern Gulf. Santa Barbara: Praeger Security International, 2007.

CORDESMAN, ANTHONY. 2005. Iran's Developing Military Capabilities, Washington D. C.: The CSIS Press.

Fars News Agency, 8. 2. 2012. Hezbollah Leader Stresses Iran's Key Role in Victories of Resistance Movements. Retrieved from July 15, 2015 from http:// english.farsnews.com/newstext.php?nn=9010174030

Fars News Agency, 8. 8. 2006. Supreme Leader Orders All to Defend Hezbollah. 
Retrieved from July 15, 2015 from http://english.farsnews.com/newstext. php?nn=8505170214

Fidh. 2007. Iran / death penalty: A state terror policy. Paris: Fédération internationale des ligues des droits de 1'Homme. Retrieved from July 15, 2015 from http://www.fidh.org/IMG/pdf/Rapport_Iran_final.pdf

FRISCH, HILLEL. 2007. The Iran-Hamas Alliance: Threat and Folly. Perspectives Paper No. 28. Retrieved from July 15, 2015 from http://www. biu.ac.i1/SOC/besa/perspectives28.pdf

HAKAKIAN, ROYA. 2011. Assassins of the Turquoise Palace. New York: Grove Press.

KRAUS, JOSEF. 2010. "Iránská podpora terorismu - hrozba nebo mýtus?", in OLDŘICH BUREŠ a TOMÁS̆ ŠMÍD (eds.), Globální bezpečnost v Obamově ére. Praha: Metropolitní univerzita Praha.

KULISH, NICHOLAS and ERIC SCHMITT. 2012. Hezbollah Is Blamed for Attack on Israeli Tourists in Bulgaria. New York Times. Retrieved from July 15, 2015 from http://www.nytimes.com/2012/07/20/world/europe/explosionon-bulgaria-tour-bus-kills-at-least-five-israelis.html?pagewanted=all\&_r=0

KUTCHERA, CHRIS. Iran: Bani Sadr on the Iranian Terror Network. Retrieved from July 15, 2015 from http://www.chris-kutschera.com/A/Bani\%20Sadr. htm

LAQUEUR, WALTER. 1999. The New Terrorism. Fanaticism and the Arms of Mass Desctrution. London: Phoenix Press.

MANNES, AARON. 2004. Profiles in terror: A Guide to Middle East Terrorist Organizations. New York: Rowman \& Littlefield Publishers, Inc.

MAREŠ, MIROSLAV. 2005. Terorismus $v \check{C} R$. Brno: Centrum strategických studií.

MARSCHALL, CHRISTIN. 2003. Iran's Persian Gulf Policy: From Khomeini to Khatami. London: Routledge.

MARTIN, GUS. 2006. Understanding Terrorism, Thousand Oaks: Sage Publications.

Ministry of National Security of Azerbaijan Republic, 14. 3. 2012. 22 People Accused of Treason and other Grave Crimes Were Detained. Retrieved from July 15, 2015 from http://www.mns.gov.az/en/news/327.html

NAPOLEONI, LORETA. 2005. Terror Incorporated: Tracing the Dollars Behind the Terror Networks. New York: Seven Stories Press.

Radio Free Europe / Radio Liberty. 17. 2. 2012. The Iran Conflict Comes To The Caucasus. Retrieved from July 15, 2015 from http://www.rferl.org/content/ iran_azerbaijan_caucasus_georgia_assassinations/24487468.html

SHAY, SHAUL. 2005. The Axis of Evil: Iran, Hizballah, and the Palestinian 
Terror. New Brunswick: Transaction Publishers.

SOLIS, GARY D. 2010. The Law of Armed Conflict: International Humanitarian Law in War. New York: Cambridge University Press.

STRMISKA, MAXMILIAN. 2001. Terorismus a demokracie: pojetí a typologie subverzivního teroristického násili v soudobých demokraciích. Brno: Mezinárodni politologicky ústav.

TAKEYH, RAY. 2006. Hidden Iran: Paradox and Power in the Islamic Republic. New York: Henry Holt and Company.

THALER, DAVID and ALIREZA NADER. 2010. Mullahs, Guards, and Bonyads: An Exploration of Iranian Leadership Dynamics. Santa Monica: RAND Corporation.

The Washington Post, 8. 12. 2004. Iraq, Jordan See Threat To Election From Iran, Retrieved from July 15, 2015 from http://www.washingtonpost.com/ wp-dyn/articles/A43980-2004Dec7.html

United States Department of State. 2005. Iran, Bureau of Democracy, Human Rights, and Labor. Retrieved from July 15, 2015 from http://www.state. gov/j/drl/rls/hrrpt/2004/41721.htm

WEHREY, FREDERIC. 2009. The Rise of Pasdaran: Assessing the Domestic Roles of Iran's Islamic Revolutionary Guards Corps. Santa Monica: RAND Corporation.

WorldTribune, 5. 1. 2010, Hamas 2010 budget mainly 'foreign aid' from Iran. Retrieved from July 15, 2015 from http://www.washingtonpost.com/wp-dyn/ articles/A12336-2004Dec19.html 